\author{
Shynkaruk Lidiia \\ Doctor of Economics, Professor, \\ Corresponding Member of the National Academy \\ of Sciences of Ukraine \\ ORCID 0000-0002-7434-1495 \\ lidia_shyn@ukr.net; \\ Salata Halyna \\ $\mathrm{PhD}$ in History, \\ Director of the College of Kiev University of Culture \\ ORCID 0000-0002-2673-8463 \\ salaty@bigmir.net \\ Danylova Tetyana \\ $\mathrm{PhD}$ in Philosophy, \\ Associate Professor of the Department of Philosophy \\ of the National University of Life and \\ Environmental Sciences of Ukraine \\ ORCID 0000-0002-0297-9473 \\ Researcher ID: C-9215-2016 \\ danilova_tv@ukr.net
}

\title{
DIALOGUE OF CULTURES: E. HALL AND F. KLUCKHOHN
}

The purpose of the study. This paper aims at highlighting some of the main approaches to intercultural dialogue - E. Hall's cultural factors and F. Kluckhohn and F. Strodtbeck's value orientations theory. Methodology. The authors have used anthropological integrative approach, comparative analysis, and philosophical hermeneutics. The scientific novelty. Cultural patterns are largely determined by different reality tunnels: everyone creates his/her own unique reality, which is recognized as the only one "true reality". This makes communication more complicated. Nowadays, global awareness and understanding of other cultures help people to cope with the "difficulties of cultural translation". To avoid the threats to effective intercultural communication, we must recognize that Other doesn't mean Wrong, Other is just Different. It helps to understand the cultural logics behind cultural differences. One-sided perception caused by cultural and historical differences can be overcome by integrating the other models of thinking, as well as by accepting the other "rules" of relations between people, including those, which have arisen under other cultural and historical conditions. This will lead to recognition that different cultural systems do not exclude, but successfully complement and enrich each other. Conclusions. Hall's theory of culture and F. Kluckhohn and F. Strodtbeck's value orientation theory contribute to better understanding of the representatives of other cultures, their attitudes towards the world and ways of communication, as well as promote the ability to be a successful intercultural dialogue's participant.

Keywords: culture, communication, intercultural communication, intercultural dialogue, E. Hall, high-context and low-context cultures, monochronic and polychronic cultures, F. Kluckhohn and F. Strodtbeck's value orientations theory.

Шинкарук Лідія Василівна, доктор економічних наук, профресор, член-кореспондент НАН України; Салата Галина Володимирівна, кандидат історичних наук, директор коледжу Київського університету культури; Данилова Тетяна Вікторівна, кандидат фрілософрських наук, доцент кафредри фрілософрії Національного університету біоресурсів і природокористування України

Діалог культур: Е. Холл і Ф. Клакхон

Мета дослідження. Стаття спрямована на висвітлення деяких основних підходів до міжкультурної комунікації - культурних факторів Е. Холла та теорії ціннісних орієнтацій Ф. Клакхон і Ф. Стродтбека. Методологія дослідження. Автори використовували антропологічний інтегральний підхід, компаративний аналіз та фрілософрську герменевтику. Наукова новизна роботи. Культурні патерни багато в чому визначаються наявністю різних тунелів реальності: кожен створює свою власну реальність, яка визнається єдиною «справжньою реальністю». Відмінності в культурних патернах викликають проблеми в міжкультурному діалозі. Сьогодні глобальна інформованість та розуміння інших культур допомагають людям впоратися зі «складнощами культурного перекладу». Для уникнення загроз ефективному міжкультурному спілкуванню ми повинні визнати, що Інший не означає Неправильний, Інший - це Відмінний. Подібне розуміння сприятиме усвідомленню культурної логіки, що прихована за культурними відмінностями. Однобічне сприйняття, спричинене культурними та історичними відмінностями, можна подолати шляхом інтеграції інших моделей мислення і прийняття інших «правил» поведінки людей, у тому числі тих, які виникли в інших культурно-історичних умовах. Це призведе до визнання того, що різні культурні системи не виключають, але успішно доповнюють і збагачують одна одну. Висновки. Теорія Е. Холла і теорія ціннісних орієнтацій Ф. Клакхон і Ф. Стродтбека сприяють кращому розумінню представників інших культур, а також надають можливості стати успішними учасниками міжкультурного діалогу.

Ключові слова: культура, комунікація, міжкультурна комунікація, міжкультурний діалог, Е. Холл, висококонтекстуальні та низькоконтекстуальні культури, монохронні та поліхронні культури, теорія ціннісних орієнтацій Ф. Клакхон та Ф. Стродтбека.

(c) Shynkaruk L., 2018

(C) Salata H., 2018

(C) Danylova T., 2018 
Шинкарук Лидия Васильевна, доктор экономических наук, профрессор, член-корреспондент НАН Украины; Салата Галина Владимировна, кандидат исторических наук, директор колледжа Киевского университета культуры; Данилова Татьяна Викторовна, кандидат философрских наук, доцент кафедры философии Национального университета биоресурсов и природопользования Украины

\section{Диалог культур: Э. Холл и Ф. Клакхон}

Цель исследования заключается в анализе некоторых основных подходов к межкультурной коммуникации - теории культурных факторов Э. Холла и теории ценностных ориентаций Ф. Клакхон и Ф. Стродтбека. Методология исследования. Авторы использовали антропологический интегральный подход, компаративный анализ и фрилософскую герменевтику. Научная новизна работы. Культурные паттерны во многом определяются наличием различных туннелей реальности: каждый создает свою собственную реальность, которая признается единственной «истинной реальностью». Различия в культурных паттернах вызывают проблемы в процессе межкультурного диалога. Сегодня глобальная информированность и понимание других культур помогают людям справиться со «сложностями культурного перевода». Для предотвращения угроз эффективному межкультурному общению мы должны признать, что Другой не означает Неправильный, Другой - это Отличающийся от нас. Это будет способствовать пониманию культурной логики, скрытой за культурными различиями. Одностороннее восприятие, вызванное культурными и историческими различиями, можно преодолеть путем интеграции иных моделей мышления и принятия иных «правил» поведения людей, в том числе и тех, которые возникли в других культурно-исторических условиях. Это приведет к признанию того, что различные культурные системы не исключают, но успешно дополняют и обогащают друг друга. Выводы. Теория Э. Холла и теория ценностных ориентаций Ф. Клакхон и Ф. Стродтбека способствуют лучшему пониманию представителей других культур, а также предоставляют возможность стать успешными участниками межкультурного диалога.

Ключевые слова: культура, коммуникация, межкультурная коммуникация, межкультурный диалог, Э. Холл, высококонтекстуальные и низкоконтекстуальные культуры, монохронные и полихронные культуры, теория ценностных ориентаций Ф. Клакхон и Ф. Стродтбека.

Introduction. The imperative of contemporary world politics is the interaction of cultures that can become decisive for the $21^{\text {st }}$ century. Since the last century, "societies around the globe have been interwoven into a complex fabric of interdependent economic, technological, political, and social relationships. This interdependency is a salient characteristic of the world we live in, and the future promises even greater interconnectivity, requiring increased cultural knowledge and language abilities" [13, 2]. It is clear that it will not be possible to establish intercultural contacts at once: meeting representatives of a foreign culture, people may experience confusion, fear, mistrust, and even aggression $[7 ; 14 ; 15 ; 17 ; 18]$. Building intercultural relationship is a double-edged sward. An intercultural dialogue in its various forms is intensified: we learn and grow getting in touch with other cultures. We open new horizons, learn to be more tolerant, respect and understand the other cultures, and enjoy the fact that the world is that diverse. We see that there are other ways of problem solving and different models of perception of the world. We expand our own set of concepts, principles, values, and ways of resolving conflicts. We explore how to overcome the emotional barriers and stereotypes of the different ways of thinking and feeling.

However, an increase in intercultural communication also brings anxiety. Challenges that threaten the very humanity exacerbate problems between members of different political, social, and religious groups [2; 9]. Thus, for successful communication and peaceful world, we have to go deeper into different cultural narratives and interpret human nature and condition from diverse cultural perspective, as well as avoid and overcome interpersonal and intercultural conflicts [3].

Literature review. Key points and ideas for successful intercultural communication were developed by G. Trager, E. Hall, C. Kluckhohn, F. Kluckhohn, F. Strodtbeck, J. Habermas, N. Luhmann, W. Goodenough, C. Geertz, G. Hofstede, V. Gudykunst and R. Brislín.

M. Mamardashvili, Y. Lotman, G. Pomerants, A. Rapoport, B. Uspensky, S. Ter-Minasova contributed to a new level of understanding of cultural phenomena and intercultural contacts. However still now, there are more questions than answers. Contemporary issues of intercultural communication are to be studied in the frame of transdisciplinary paradigm.

The purpose of the study. This paper aims at highlighting some of the main approaches to intercultural dialogue - E. Hall's cultural factors and F. Kluckhohn and F. Strodtbeck's value orientations theory.

Methodology of the study. The authors have used anthropological integrative approach, comparative analysis, and philosophical hermeneutics.

Theoretical basis and results. The field of intercultural communication is relatively new - its boundaries were identified in the second half of the $20^{\text {th }}$ century. Intercultural communication is deeply rooted into cultural anthropology. Thus, culture may be seen as a core of intercultural dialogue. The prominent American anthropologist E. Hall was a founder of intercultural communication as a special field of knowledge. In his works, he demonstrated that the worldview and human conduct were largely determined by a whole set of unconscious cultural patterns. In "The Silent Language" he outlined the theory of culture in general and the way it controlled human behavior. According to E. Hall, culture is "a mold in which we are all cast, and it controls our daily lives in many unsuspected ways" [4, 52]. In "The Hidden Dimension" [6] he introduced a new science - proxemics. Proxemics studies how humans use space when they are communicating. Later he introduced his integral vision of culture in his book "Beyond Culture": "Culture is man's medium; there is not 
one aspect of human life that is not touched and altered by culture. This means personality, how people express themselves (including shows of emotions), the way they think, how they move, how problems are solved, how their cities are planned and laid out, how transportation systems function and are organized, as well as how economic and government systems are put together and function. However, like the purloined letter, it is frequently the most obvious and taken-for-granted and therefore the least studied aspects of culture that influence behavior in the deepest and subtlest ways" [5, 16-17].

E. Hall proposed his interpretation of culture and communication: "Communication is culture - culture is communication" that immediately became a hot topic in the scientific debates. This led to the emergence of specialized journals, in which the problems related to communication and culture were discussed. Identifying communication and culture, E. Hall emphasized that human behavior, their gestures, speech patterns had a symbolic, informational function in communication. The linguistic code exists in parallel with the cultural one, which is rooted in the non-verbal coordinate system [4].

Communication behavioral patterns are not often recognized and taken for granted. Not everything is verbalized - what people do is often a more important parameter. However, Europeans are accustomed to the "world of words" and quite often do not interpret communication through the lens of the language of behavior: even using seemingly understandable words, one can incorrectly interpret the voice of the different cultural discourse. E. Hall interpreted culture as the way of people's living, as the sum of their assimilated patterns of behavior, attitudes, and material things [4]. Culture governs personal or group behaviors and the models of this control are beyond the conscious control of the individual. "The Silent Language" represents the theory of culture and its origin. The main message of the book is that people must be aware of our cultural unconscious. "Culture hides much more than it reveals, and strangely enough what it hides, it hides most effectively from its own participants. Years of study have convinced me that the real job is not to understand foreign culture, but to understand our own" $[4,53]$. This can be achieved through immersion into the other modes of cultural awareness breaking through culture shock.

Representatives of different cultures are captives of their own models, systems of values, perceptions, interpretations, explanations, modes of conduct, etc. [1]. According to E. Hall, the main goal of going deeper into intercultural communication is to study the needs of the representatives of different cultures to improve their communication skills. He was the first to study and explain communication as an activity that could be analyzed. This allowed him to develop his theory of cultural patterns of interaction. E. Hall suggested dividing cultures into two types: high-context and low-context, that is, he compared cultures depending on their relation to the context. The level of context determines the type of communication inherent in culture. " $A$ high-context $(\mathrm{HC})$ communication or message is one in which most of the information is either in the physical context or internalized in the person, while very little is in the coded, explicit, transmitted part of the message. A low-context (LC) is just the opposite; i.e., the mass of the information is vested in the explicit code" [5, 91].

$\mathrm{HC}$ refers to groups or societies, where people have close connections over a long period of time. Thus, people usually know what to do, how to do, and what to think. Relationships are quite stable and are based on trust. Human identity is deeply rooted in groups. Interests of their in-groups are more important than of the members of the out-groups. Representatives of $\mathrm{HC}$ culture highly use non-verbal communication while verbal messages are implicit, context is more important than words. Around $70 \%$ of the world is highcontext [16]. Examples of high context countries include China, Japan, Korea, the Arab countries. These cultures remain virtually unchanged over time. Therefore, much is predictable and the detailed analysis of daily life is not that necessary. The representatives of $\mathrm{HC}$ cultures pay significant attention to the status, hierarchy, appearance, and way of communication. A large number of hints, subtexts, metaphors, etc. is used. For example, if at the negotiation table a representative of LC culture says "Yes", it means the proposal is accepted. Within HC Japanese culture, Japanese "Yes" can mean "Yes", "No" or "Maybe". This is due to the fact that in business relationships they cannot tell the person "No" and put them in an awkward position, they are afraid of offending and upsetting people and undermining interpersonal relationships.

In LC cultures, people tend to have many connections but of shorter duration or for some specific reason. Cultural behavior and beliefs may need to be spelled out explicitly so that those coming into the cultural environment know how to behave. Relationships are not that stable like in HC cultures, they may begin quickly and end soon. People are mostly goal-oriented and follow procedures to get things done. Unlike HC cultures, social structure is decentralized and human identity is rooted in oneself and their accomplishments. Context here is less important than words. Thus, verbal communication is direct and explicit - it's a way of exchanging information. Examples of low context cultures include Germany, Scandinavia, the United States.

During communication, HC representatives may consider LC representatives to be aggressive, naive, impatient, and arrogant. In turn, the latter believe that the first are difficult to understand: they are insecure, indecisive, and evade giving direct answers. As R. Wilson described it, "Prof. X, who is Japanese, shares the same model of gravity as Prof. $Y$, who is Swedish, because they are both physicists; but Prof. X still lives in a Japanese reality-tunnel when relating to family and friends and Prof. $Y$ is in a Swedish realitytunnel when outside the lab in Swedish society. This is why, when not discussing physics, Prof. $X$ might seem stiff or formal to Prof. Y, who might in turn seem rude or even crude to Prof. X" [19, 15].

Time models also determine the communicative behavior of people. E. Hall proposed a theory of monochronic (M-time) and polychronic (P-time) cultures. The first system of time (M-time) is characterized by 
focusing on one thing within a given time period, "M-time emphasizes schedules, segmentation, and promptness" $[5,17]$. Representatives of monochronic cultures perceive time linearly: it splits into segments and is structured. For them it is very important to plan their time. Time appears as a reality of a certain value. The famous phrase "time is money" arises within this context. Time is the same private property as material things. The representatives of monochronic cultures are clearly focused on one action. They are punctual, responsible, and adhere to all arrangements. Within interpersonal relations, time is perceived the same way. The negative reaction to interference in the activity as well as the idea of the inviolability of the personal sphere is an indisputable principle in this type of culture. This time perception is typical for the representatives of the United States, Canada, Northern European countries, Germany, Switzerland, Great Britain.

"P-time systems are characterized by several things happening at once. They stress involvement of people and completion of transactions rather than adherence to preset schedules" [5, 17]. Polychronic time perception is inherent in Latin American, Arab part of Mediterranean, Sub-Sahara, Native American Indian cultures. For them every day, every event conceals what is coming next, i.e., something unknown, unpredictable. Time management is not a priority. Within these cultures, communication with others plays a more important role than the results of activity. "Polychronic people" can do many things at once. For them time does not that significant - they can often change their plans. Whether they are punctual depend on the relationships with others. "Advance notice is often referred to in America as "lead time", an expression which is significant in a culture where schedules are important. While it is learned informally, most of us are familiar with how it works in our own culture, even though we cannot state the rules technically. The rules for lead time in other cultures, however, have rarely been analyzed. At the most they are known by experience to those, who lived abroad for some time. Yet think how important it is to know how much time is required to prepare people, or for them to prepare themselves, for things to come. Sometimes lead time would seem to be very extended. At other times, in the Middle East, any period longer than a week may be too long" $[4,26]$.

Different ways of handling time may lead to intercultural conflicts; thus cultural awareness is required. When we divide cultures into high-context and low-context, monochronic and polychronic, we must remember that each of these types of cultures presupposes their own rules of conduct that govern people's lives.

Cultural differences can be obvious or subtle. The way people dress, behave, eat or drink is quite obvious. However, there are less obvious differences that we take for granted within our cultural space. These subtle cultural differences are shared perceptions, which lead to actions and behaviors that are appropriate within a certain culture. Cultural patterns exist in a human mind. They encompass beliefs, values, and norms, which shape our perception of the world.For successful intercultural communication, people must be aware of their own in-group perceptions, cultural patterns (which are often unconscious) and about those of the other cultural groups. F. Kluckhohn and F. Strodtbeck's value orientations theory [11] is a useful tool for framing cultural patterns. This theory outlines five basic human problems that are common to all peoples at all times and all places: innate predisposition, man's relation to nature, time dimension, valued personality type, and relationship pattern.

The first value orientation spoke to the inherent nature of a human: is he/she basically good, evil or mixed, and whether we can change ourselves by learning? For instance, F. Kluckhohn described American view of human nature as evil and perfectible, which had grown out of the Puritan heritage [10]. On the other hand, Japanese believe that people are inherently good, and this innate predisposition remains unchanged. Such views are largely attributable to the strong influence of Shinto on Japanese culture and system of values [20].

The second value orientation - human's relationship to nature - provides several options: subjugation to nature, harmony with nature, and mastery over nature. The idea of active reorganization of the world inherent in the Western mentality (mastery over nature) is in opposition to Japanese propensity to perceive Man - Nature unity/harmony.

The third value orientation deals with time dimension. According to F. Kluckhohn [10], each society has its own understanding of the past, present and future. Societies differ in which of these dimensions they emphasize. While dominant American culture is future-oriented and looks ahead, its representatives plan and set goals, strive for change and grow, past-oriented cultures like Japan, China, Korea value tradition and experience and tend to view them as a guide when making decisions.

The fourth value orientation describes the modality of human activity (valued personality type) - orientation on activity itself, being or being-in-becoming. Representatives of active type of culture (primarily Western cultures) prefer activities that lead to achievements, which are measurable. Being-in-becoming is self-determination through relationships with elements of self-development. In being-oriented cultures a sense of identity is based on stable relationships and stable social structure - people succeed as a team or fail alone. It is typical for Chinese, Japanese, Arab cultures.

The fifth value orientation is modality of human relations. F. Kluckhohn proposed three models (orientations): individualistic, collateral, and linear. The first one is typical for North American culture, where family ties are relatively limited and not so intensive. This model of relationship is focused on individual or nuclear family. Collateral model represents more intense family ties that go beyond the nuclear family and include grandparents, uncles, aunts, cousins, etc. It focuses on consensus within a large peer group. Linear 
model is similar to collateral. However, within it the concept of family covers all distant relatives: tribes, clans, even deceased ancestors, who influence people in decision making. In this case, hierarchical principles and recognition of higher authority in the group are clearly expressed. This model is typical for many Eastern cultures.

The scientific novelty. These patterns are largely determined by different reality tunnels - emic realities established by a system of coding, or a structure of metaphors, and transmitted by means of language, arts, mathematics or other symbolic systems [19]. People perceive and interpret the world through a certain set of filters, which may be different in different cultures. Everyone creates his/her own unique reality, which is recognized as the only one "true reality" [12]. Furthermore, intercultural communication largely depends on the communicative competence of dialogue participants. These differences essentially influence the success of the communicative process. Participants use special language options and discursive strategies, which may be quite different in any given culture. This makes communication more complicated. These cultural differences are a communicative barrier that must be overcome. Such distinctions in cultural patterns cause difficulties in intercultural dialogue. Nowadays, global awareness and understanding of other cultures help people to cope with the "difficulties of cultural translation".

One of the peculiarities of intercultural dialogue is the problem of mutual understanding due to complete or partial ignorance of matrices of another culture. Different cultural identities form different stereotypes at perceptual level: there is a huge gap between our in-group (our cultural group) and out-groups (other cultural groups). At attitudinal level, stereotypes can become prejudice. We form our preconceived opinions and judgments about other groups, which, in fact, are not based on experience or reason. The negative form of prejudice can lead to discrimination at behavioral level. To avoid these threats to effective intercultural communication, we must recognize that Other doesn't mean Wrong, Other is just Different. It helps to understand the cultural logics behind cultural differences. One-sided perception caused by cultural and historical differences can be overcome by integrating the other models of thinking, as well as by accepting the other "rules" of relations between people, including those, which have arisen under other cultural and historical conditions. This will lead to recognition that different cultural systems do not exclude, but successfully complement and enrich each other.

Conclusions. In intercultural dialogue, representatives of different cultures face great difficulties in communication and mutual understanding, because their perceptions, emotions, thoughts and behaviors may vary significantly. Hall's theory contributes to better understanding of the representatives of the other cultures, their attitudes towards the world and ways of communication, as well as promotes the ability to be a successful intercultural dialogue's participant. This theory gave impetus to the study of the dialogues of cultures. F. Kluckhohn and F. Strodtbeck provided a wide range of opportunities for the further development of their theory [8]. Their theory initiated further research, which, in turn, gave rise to the new theories that contributed to the understanding of humans and their interactions.

\section{תimepamypa}

1. Шинкарук В.Д., Салата Г.В., Данилова Т.В. Дихотомія «культура - цивілізація» в англоамериканському і західноєвропейському науковому дискурсі. Вісник Національної академії керівних кадрів культури і мистецтв. 2018. №2. С. 82-87.

2. Danylova T.V. The Desire for Recognition in the Context of Francis Fukuyama's Universal History. Anthropological Measurements of Philosophical Research. 2016. Is.10. P. 69-77. Doi 10.15802/ampr.v0i10.87303.

3. Danylova T.V. Searching for the True Self: The Way of Nondual Wisdom. Anthropological Measurements of Philosophical Research. 2017. Is.12. P. 7-15. Doi 10.15802/ampr.v0i12.119069.

4. Hall E. The Silent Language. New York: Doubleday \& Company, INC., 1959. 241 p.

5. Hall E. T. Beyond Culture. Anchor Books/Doubleday, 1976. 320 p.

6. Hall E. The Hidden Dimension. Anchor, 1990. 240 p.

7. Herzog C. Intercultural communication conflicts. GRIN Verlag, 2010. 40 p.

8. Hills M. Kluckhohn and Strodtbeck's Values Orientation Theory. Online Readings in Psychology and Culture. 2002. 4(4). Retrieved from http://dx.doi.org/10.9707/2307-0919.1040].

9. Khmil V., Malivskyi A. Contemporary Reception of Rene Descartes' Skepticism. Philosophy and Cosmology. 2017. Vol. 19. P. 168-178.

10. Kluckhohn F. Dominant and variant value orientations. Personality in nature, society, and culture / C. Kluckhohn \& H. Murray (Eds.) NY: Alfred A. Khopf, 1953. P. 342-357.

11. Kluckhohn F., Strodtbeck F. Variations in Value Orientations. New York: Row, Peterson and Co., USA, $1961.187 \mathrm{p}$. 2003. $245 \mathrm{p}$

12. O'Connor J., Seymour J. Introducing NLP Neuro-Linguistic Programming. Thorsons; (Reissue) edition,

13. Samovar L.A., Porter R.E., McDaniel E.R. Communication between Cultures. Wadsworth Publishing; 7 edition, 2009. $480 \mathrm{p}$

14. Storozhuk S.V., Hoyan I.M. Gender Equality as a Modern Phenomenon. Anthropological Measurements of Philosophical Research. 2017. Is. 11. P. 71-83. DOI: 10.15802/ampr.v0i11.105481

15. Storozhuk S., Goian I. Gender Existence: Correlation Between Equality and Identity. Philosophy and Cosmology. 2017. Vol. 18. P. 208-218.

16. Tung R. International Organizational Behaviour. Luthans Virtual OB. McGraw-Hill, 1995. P. 487-518. 
17. Yablonska T., Dembytska N., Vus V. Social-psychological Adjustment of Ex-servicemen to Civilian Life. Social Welfare Interdisciplinary Approach. 2017. Vol. 7. Is. 1. P. 168-177. DOI: 10.21277/sw.v1i7.285

18. Vus V., Kychkyruk T., Lokutova E. Social and Personal Development of Preschoolers Through The Lens of Parental Religious Educational Models. Science and Education. 2018. Is. 1. P. 60-64. DOI: https://doi.org/10.24195/2414-4665-2018-1-8.

19. Wilson R.A. The New Inquisition. Irrational Rationalism and the Citadel of Science. Falkon Press, Phoenix, Arisona, USA, 1987. 240 pp.

20. Yamakage M. The essence of Shinto: Japan's spiritual heart / P. De Leeuw \& A. Rankin, Eds. Tokyo: Kodansha International, 2006. 232 p.

\section{References}

1. Shynkaruk, V.D., Salata, G.V., \& Danylova, T.V. (2018). The Dichotomy "Culture - Civilization" in the AngloAmerican and Western European Scientific Discourse. National Academy of Managerial Staff of Culture and Arts Herald, 2, 82-87 [in Ukrainian].

2. Danylova, T.V. (2016). The Desire for Recognition in the Context of Francis Fukuyama's Universal History. Anthropological Measurements of Philosophical Research, 10, 69-77. Doi 10.15802/ampr.v0i10.87303.

3. Danylova, T.V. (2017). Searching for the True Self: The Way of Nondual Wisdom. Anthropological Measurements of Philosophical Research. 12, 7-15. Doi 10.15802/ampr.v0i12.119069.

4. Hall, E. (1959). The Silent Language. New York: Doubleday \& Company, INC.

5. Hall, E. T. (1976). Beyond Culture. Anchor Books/Doubleday.

6. Hall, E. (1990). The Hidden Dimension. Anchor.

7. Herzog, C. (2010). Intercultural communication conflicts. GRIN Verlag.

8. Hills, M. (2002). Kluckhohn and Strodtbeck's Values Orientation Theory. Online Readings in Psychology and Culture, (4). Retrieved from http://dx.doi.org/10.9707/2307-0919.1040].

9. Khmil, V., \& Malivskyi, A. (2017). Contemporary Reception of Rene Descartes' Skepticism. Philosophy and Cosmology, 19, 168-178.

10. Kluckhohn, F. (1953). Dominant and variant value orientations. In C. Kluckhohn \& H. Murray (Eds.), Personality in nature, society, and culture (pp. 342-357). NY: Alfred A. Khopf.

11. Kluckhohn, F., \& Strodtbeck, F. (1961). Variations in Value Orientations. New York: Row, Peterson and Co.

12. O'Connor, J., Seymour, J. (2003). Introducing NLP Neuro-Linguistic Programming. Thorsons; (Reissue) edition.

13. Samovar, L.A., Porter, R.E., \& McDaniel, E.R. (2009). Communication between Cultures. Wadsworth Publishing; 7 edition.

14. Storozhuk, S.V., \& Hoyan, I.M. (2017). Gender Equality as a Modern Phenomenon. Anthropological Measurements of Philosophical Research, 11, 71-83. DOI: 10.15802/ampr.v0i11.105481

15. Storozhuk, S., \& Goian, I. (2017). Gender Existence: Correlation Between Equality and Identity. Philosophy and Cosmology, 18, 208-218.

16. Tung, R. (1995). International Organizational Behaviour. In Luthans Virtual OB (pp. 487-518). McGraw-Hill.

17. Yablonska, T., Dembytska, N., \& Vus, V. (2017). Social-psychological Adjustment of Ex-servicemen to Civilian Life. Social Welfare Interdisciplinary Approach, 7 (1), 168-177. DOI: 10.21277/sw.v1i7.285

18. Vus, V., Kychkyruk, T., \& Lokutova, E. (2018). Social and Personal Development of Preschoolers Through the Lens of Parental Religious Educational Models. Science and Education, 1, 60-64. DOI: https://doi.org/10.24195/2414-4665-2018-1-8.

19. Wilson R.A. (1987). The New Inquisition. Irrational Rationalism and the Citadel of Science. Falkon Press, Phoenix, Arizona, USA.

20. Yamakage, M. (2006). The essence of Shinto: Japan's spiritual heart. P. De Leeuw \& A. Rankin (Eds.). Tokyo: Kodansha International.

Стаття надійшла до редакції 15.04.2018 p. 